\title{
The maintenance of pregnancy in hypophysectomized goats
}

\author{
H. L. Buttle
}

National Institute for Research in Dairying, Shinfield, Reading RG2 9AT, U.K.

\begin{abstract}
Summary. Pregnancy in goats is maintained after hypophysectomy at about Day 90 of gestation by injection of $20 \mathrm{mg}$ progesterone or $1 \mathrm{mg} \mathrm{LH} /$ day, but not by $5 \mathrm{mg}$ prolactin/ day.
\end{abstract}

\section{Introduction}

The maintenance of pregnancy in goats is dependent upon the secretion of progesterone by the corpus luteum $(\mathrm{CL})$ for the duration of gestation; there is no significant placental production of progesterone in goats as there is in sheep (Linzell \& Heap, 1968). An intact pituitary gland is necessary for the maintenance of the $\mathrm{CL}$ in the pregnant goat because hypophysectomy at any stage of pregnancy results in abortion a few days later (Cowie, Daniel, Prichard \& Tindal, 1963). In hysterectomized-hypophysectomized sheep prolactin by itself is capable of maintaining the structure and progesterone content of the $\mathrm{CL}$, but $\mathrm{LH}$ and prolactin together result in increased progesterone content of the CL (Denamur, Martinet \& Short, 1973). Sheep hypophysectomized before Day 20 of pregnancy will maintain that pregnancy when given prolactin and LH (Kann \& Denamur, 1974). However, the importance of prolactin in the luteotrophic complex of sheep is controversial; Nalbandov (1973) denies any action of prolactin upon CL maintenance in sheep and considers LH alone to be luteotrophic in ewes hypophysectomized during the oestrous cycle. The demonstration of specific prolactin receptors in luteal tissue (Saito \& Saxena, 1975) suggests an action of prolactin upon luteal cells but does not define that activity.

Sheep and goats secrete large amounts of placental lactogen from mid-pregnancy until term (Buttle, Forsyth \& Knaggs, 1972; Kelly, Robertson \& Friesen, 1974; Djiane \& Kann, 1975; Currie, Kelly, Friesen \& Thorburn, 1977) and because placental lactogen has several activities similar to those of prolactin (Forsyth, 1974) the present study was undertaken to determine which pituitary hormones were responsible for the maintenance of the $\mathrm{CL}$ and pregnancy in goats, and whether placental lactogen could form any part of the luteotrophic complex in this species.

\section{Materials and Methods}

Primiparous and multiparous British Saanen goats, aged 2-6 years, from the Institute's herd were used.

Hypophysectomy was performed via a parapharyngeal incision by the transphenoid method of Cowie \& Tindal (1961). In particular, much attention was given to the removal of the pituitary stalk so that the whole of the stalk foramen could be seen. After removal of pituitary tissue the sella was examined for remnants by using a $2.8 \mathrm{~mm}$ diameter cystoscope (G.U. Manufacturing Co. Ltd). The sella was then carefully swabbed with Zenker-formol solution to destroy any pituitary fragments, care being taken to prevent the solution entering the stalk foramen and thus damaging brain tissue.

Hormonal treatments were initiated immediately after hypophysectomy. Each animal was given a subcutaneous implant of one 50-mg compressed tablet prepared from pure dexamethasone powder (Ciba-Geigy Ltd, Horsham, Sussex, U.K.). Progesterone (20 mg: Koch-Light, Colnbrook, Bucks, U.K.), dissolved in $1 \mathrm{ml}$ benzyl alcohol/arachis oil $(1: 10 \mathrm{v} / \mathrm{v})$, was injected intramuscularly once a day. Prolactin (NIH-P-S6 $\cong 25$ i.u./mg) and LH (NIH-LH-S1 or $-\mathrm{S} 19,1.00$ and 1.01 i.u./mg respectively) were prepared fresh each day in 1 or $2 \mathrm{ml} 0.154 \mathrm{M}-\mathrm{NaCl}$ and injected subcutaneously twice a day at 09:00 and 18:00 h, unless otherwise stated. The animals were housed in individual pens in a room maintained at $20-25^{\circ} \mathrm{C}$. 
Blood samples were taken by jugular venepuncture immediately before the morning hormone injection, and also at hourly intervals throughout one of the days during hormone treatment. A few hours before autopsy goats were injected intravenously with $100 \mu \mathrm{g}$ TSH-releasing factor (TRF: ICI Ltd) in $1 \mathrm{ml}$ water, or with $2.5 \mathrm{mg}$ reserpine (BDH Ltd, Poole, U.K.) suspended in $2.5 \mathrm{ml} 0.154 \mathrm{M}-\mathrm{NaCl}$. Blood samples were taken 5,10,20 and $30 \mathrm{~min}$ after the injection. The plasma was separated and stored at $-20^{\circ} \mathrm{C}$ until assayed.

At autopsy the fetuses, if present, were examined for heart beat and the crown-rump length was measured. Fetal crown-rump length was used to determine the age of the fetus and so indicate survival of fetuses after maternal hypophysectomy: in a series of 11 fetuses measured at 89-91 days of gestation the mean crown-rump length was $22.3 \pm 1 \cdot 13$ (s.d.) $\mathrm{cm}$, the range being $20.5-24.0 \mathrm{~cm}$. The maternal ovaries were examined macroscopically and $\mathrm{CL}$ were dissected out and weighed. The maternal heads were perfused via the carotid arteries with $0.154 \mathrm{M}-\mathrm{NaCl}$ solution followed by $15 \%$ formalin in $0.154 \mathrm{M}-\mathrm{NaCl}$. The pituitary sella and the forebrain overlying the sella were cut out and processed for histology (Cowie \& Tindal, 1961). Serial sections were cut at $6 \mu \mathrm{m}$, every 20th section mounted, stained with haematoxylin and eosin and examined for pituitary gland remnants. The volumes of pituitary gland remnants were estimated by projection of sections onto graph paper and summing the area covered by apparently viable and indeterminate tissue. The tissue was classified into three types corresponding to pars distalis (anterior pituitary), pars nervosa (posterior pituitary) and pars tuberalis. Three sellae turcicae with intact pituitary glands were used to estimate the normal amount of tissue occurring in each category and the proportional volumes estimated by this method were $93.5 \%$ anterior pituitary, $5.0 \%$ posterior pituitary and $1.5 \%$ pars tuberalis.

The goats were assigned to an experimental group immediately after successful hypophysectomy. The experiments (Table 1) with progesterone were carried out on 5 goats, in 1973-1974; those involving prolactin ( 5 goats) and LH (4 goats) were done in 1974-1976.

Plasma progesterone concentrations were measured by radioimmunoassay (Furr, 1973), with an antiserum raised against progesterone- $11 \alpha$-succinyl-bovine serum albumin: the steroids showing significant cross-reaction with this antiserum were $11 \alpha$ - and $11 \beta$-hydroxypregn-4-ene-3,20-diones and $5 \alpha$-and $5 \beta$-pregnane-3,17-diones. The minimum detectable concentration was $0.5 \mathrm{ng}$ progesterone $/ \mathrm{ml}$ plasma. The intra- and inter-assay coefficients of variation were $6.8 \%$ and $14 \%$ respectively. Plasma prolactin concentrations were measured by radioimmunoassay (Buttle et al., 1972) with an antiserum raised against ovine prolactin, NIH-P-S6, which showed no cross-reactions with goat placental lactogen, ovine growth hormone, LH, FSH or TSH. The minimum detectable concentration was $1 \cdot 3 \pm 0 \cdot 55$ (s.d.) ng ovine prolactin $/ \mathrm{ml}$ plasma. The inter-assay coefficient of variation was $12.5 \%$.

\section{Results}

\section{Progesterone treatment}

Three goats were given $20 \mathrm{mg}$ progesterone/day for 7 days after hypophysectomy and none aborted during the treatment; all aborted $2 \frac{1}{2}-5$ days after withdrawal of progesterone, but in only one had the fetuses increased in length from that expected at 90 days (Table 1). The goats treated with $20 \mathrm{mg}$ progesterone/day for 9 or 10 days did not abort during treatment. They were killed 1 day after the last progesterone injection and in both the fetuses were alive and had grown in length (Table 1). The maternal ovaries were examined macroscopically only and the CL were all judged to be 'regressing' or 'regressed'. Very small amounts of anterior pituitary tissue were found in the 2 goats which also had substantial fragments of posterior pituitary gland present, and 3 goats still had some pars tuberalis tissue adherent to the median eminence (Table 1).

\section{Prolactin treatment}

All the goats treated with 1 or $5 \mathrm{mg}$ prolactin daily for 5 or 6 days aborted during the treatment period (Table 1). Peripheral plasma progesterone concentrations fell 3-4 days after hypophysectomy despite prolactin treatment (see Text-fig. 1): in each goat abortion occurred 1-2 days after the con- 


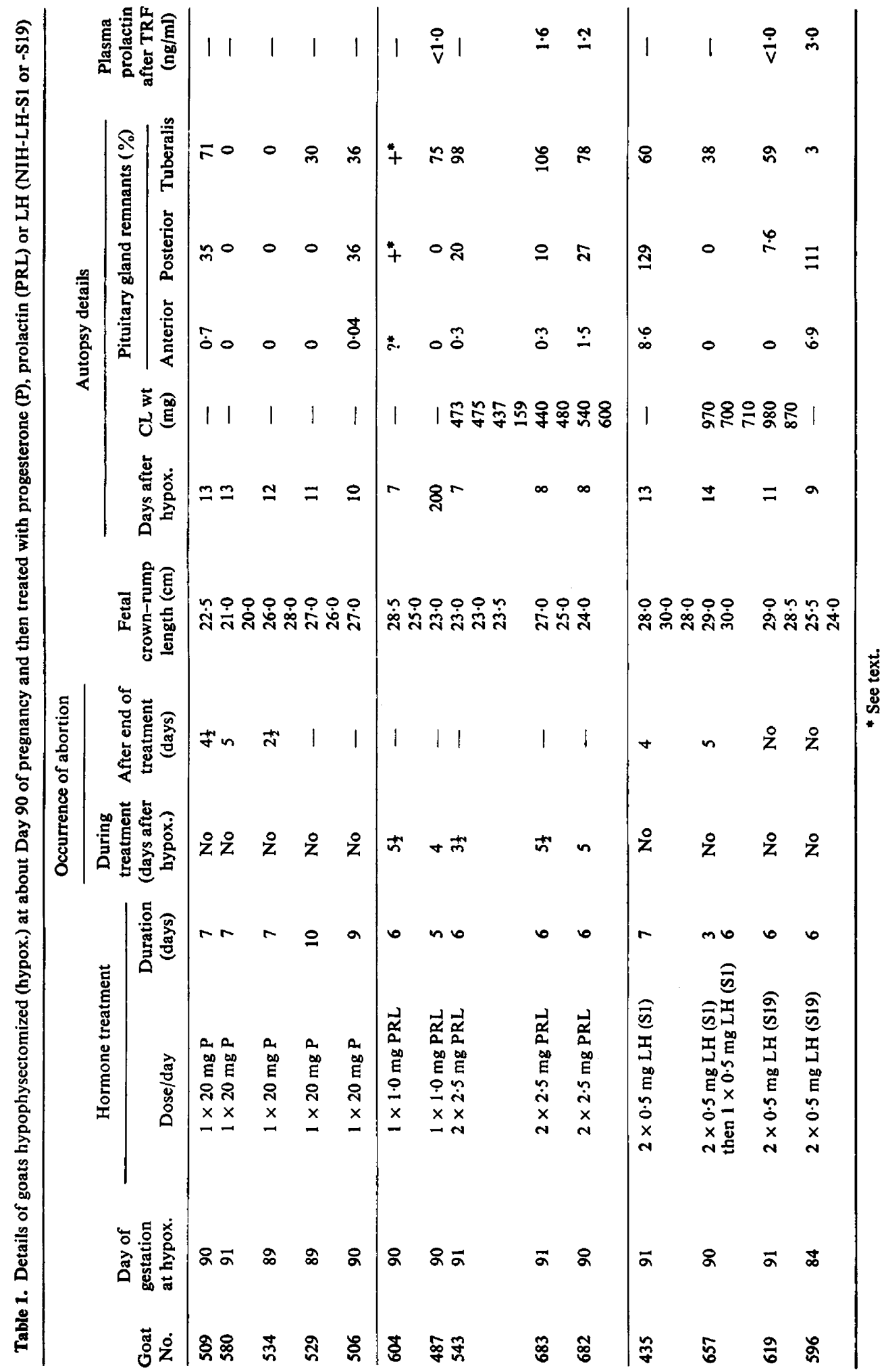


centration had fallen to near or below $1 \mathrm{ng}$ progesterone/ml plasma. The fetuses in 2 of the goats appeared to have grown after the time of hypophysectomy. All or most of the pars tuberalis was still attached to the median eminence in 4 of these goats (Table 1): the sella turcica of Goat 604 was examined macroscopically only and contained $2 \mathrm{~mm}$ of pituitary stalk attached to the median eminence and a small fragment of posterior pituitary tissue.

In the 3 goats treated with $5 \mathrm{mg}$ prolactin/day the lowest concentration of prolactin was found in the samples taken immediately before the morning injection ( 18 samples, range 4-26 ng/ml). These same goats, when sampled hourly, had maximum concentrations of $40-60 \mathrm{ng}$ prolactin/ml plasma $3-4 \frac{1}{2} \mathrm{~h}$ after injection but by $9 \mathrm{~h}$ after injection the concentrations had fallen to $20-30 \mathrm{ng}$ prolactin/ml plasma.

An injection of TRF into 3 goats resulted in no prolactin in the plasma of one and the minimum detectable amount in the other two (Table 1).

\section{LH treatment}

None of 4 goats aborted whilst receiving LH (Table 1) and the peripheral plasma progesterone concentrations remained high until after the end of LH treatment (Text-fig. 1). The length of the fetuses at examination indicated that fetal growth had occurred in all 4 goats after hypophysectomy. Two goats ( 619 and 596) were killed before abortion had occurred and in both the fetuses were still alive.

Variable amounts of pituitary tissue were present in these 4 goats (Table 1). Plasma samples taken from all 4 goats during and after treatment with $\mathrm{LH}$ contained no prolactin, but injection of $100 \mu \mathrm{g}$ TRF resulted in a plasma prolactin concentration of $3 \mathrm{ng} / \mathrm{ml}$ in Goat 596, indicating the presence of some prolactin-secreting cells. In other goats in which large fragments of anterior pituitary gland were left after attempted hypophysectomy the concentration rose to $40-68 \mathrm{ng}$ prolactin $/ \mathrm{ml}$ by $10 \mathrm{~min}$ after injection of $100 \mu \mathrm{g}$ TRF.

As part of another experiment 4 goats were hypophysectomized on Days 60-63 of pregnancy and were given $0.5 \mathrm{mg} \mathrm{LH}$ (NIH-LH-S19) twice daily for 3 days. Two goats aborted 2-3 days after hypophysectomy and in both the progesterone concentrations had fallen to $1.0 \mathrm{ng} / \mathrm{ml}$ or less by the $3 \mathrm{rd}$ day. Pregnancy was maintained in the other 2 goats in which the progesterone concentrations were still high $(12.5$ and $15 \cdot 2 \mathrm{ng} / \mathrm{ml})$ at 3 days after hypophysectomy.
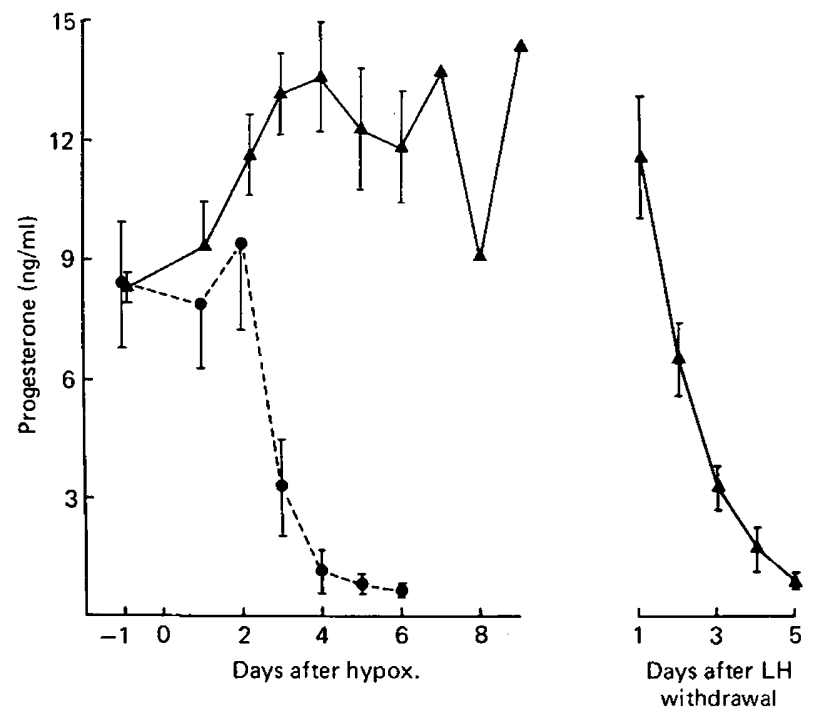

Text-fig. 1. Mean \pm s.e.m. peripheral plasma progesterone concentrations of goats hypophysectomized at about Day 90 of gestation and treated with prolactin $(\bullet, 1$ or $5 \mathrm{mg} /$ day $)$ or $\mathrm{LH}(\Delta, 1 \mathrm{mg} /$ day $)$. 
In the early stages of the experiment reserpine was used as a test to release prolactin from pituitary fragments in those animals for which there are no data for prolactin concentrations after TRF (Table 1). However, this compound failed to release prolactin in other partly hypophysectomized goats and therefore could not be used as an indicator of hypophysectomy.

\section{Discussion}

During late pregnancy, intact goats produce approximately $22 \mathrm{mg}$ progesterone/day mainly from the CL (Heap, Bedford \& Linzell, 1975). After hypophysectomy at about Day 90 of gestation injections of $20 \mathrm{mg}$ progesterone/day are capable of maintaining pregnancy in the goat (i.e. live and growing fetuses), suggesting that the only involvement of the pituitary hormones is in the maintenance of the CL. Prolactin at dose levels of 1 or $5 \mathrm{mg} /$ day was not capable of maintaining progesterone secretion for more than 2 days after hypophysectomy and abortion occurred in all animals soon after the peripheral progesterone concentration had fallen to $1 \mathrm{ng}$ progesterone $/ \mathrm{ml}$ plasma or less. This finding is in contrast to that with hysterectomized-hypophysectomized sheep, in which $10 \mathrm{mg}$ prolactin, given as 4 intramuscular injections, per day are capable of maintaining the CL (Denamur et al., 1973). In the present study, the $5 \mathrm{mg}$ dose should have been adequate as the plasma prolactin concentrations in these goats equalled or exceeded those found in intact pregnant goats.

Treatment with $1 \mathrm{mg} \mathrm{LH} /$ day maintained pregnancy for the duration of treatment in all 4 goats hypophysectomized around Day 90 , and the peripheral progesterone concentrations were maintained at normal or slightly elevated levels. Pregnancy maintenance in only 2 of 4 goats hypophysectomized on Day 60 can be explained if there is an involvement of placental lactogen. Placental lactogen secretion is well established by Day 90 of pregnancy, but is only just beginning at Day 60 (Currie et al., 1977 ), and in the 2 goats that aborted the placental lactogen secretion may have been insufficient to interact with the exogenous $\mathrm{LH}$ to maintain adequate progesterone secretion from the CL.

Total hypophysectomy is impossible in some goats because pars tuberalis tissue can extend over the base of the forebrain. In most of the animals in this study, substantial amounts of pars tuberalis tissue were found attached to the median eminence at autopsy but this tissue and that of posterior pituitary fragments have no gonadotrophic role and cannot support pregnancy in sheep or goats (Cowie et al., 1963; Kaltenbach, Graber, Niswender \& Nalbandov, 1968; present study). The presence of nearly $10 \%$ anterior pituitary tissue in 2 goats in this study was not sufficient to maintain the CL.

The injection of TRF as a test to release prolactin from any pituitary fragments may prove to be a useful indication of the amount of tissue remaining after hypophysectomy, but as yet not enough animals have been studied to draw any firm conclusions.

It is concluded that, for goats at about Day 90 of gestation, LH but not prolactin is an essential component of the luteotrophic complex. However, prolactin may interact with $\mathrm{LH}$ in its luteotrophic functions in non-pregnant goats and in pregnant goats before Day 60, and a placental lactogen could replace prolactin in this gonadotrophic function. This possibility may be clarified by current experiments with hysterectomized-hypophysectomized goats, and goats hypophysectomized earlier in pregnancy.

I thank Dr A. T. Cowie for instruction and help with hypophysectomy of goats, Mr A. Turvey for histological preparations and Mrs Denise Belson for her excellent technical assistance.

\section{References}

Buttle, H.L., Forsyth, I.A. \& Knaggs, G.S. (1972) Plasma prolactin measured by radioimmunoassay and bioassay in pregnant and lactating goats and the occurrence of a placental lactogen.J. Endocr.53,483491.

CowiE, A.T. \& Tindal, J.S. (1961) Hypophysectomy of the goat. $J$. Endocr. 22, 313-320.
Cowie, A.T., Daniel, P.M., Prichard, M.M.L. \& THNDAL, J.S. (1963) Hypophysectomy in pregnant goats, and section of the pituitary stalk in pregnant goats and sheep. J. Endocr. 28, 93-102.

Currie, W.B., Kelly, P.A., Friesen, H.G. \& Thorburn, G.D. (1977) Caprine placental lactogen : levels of prolactin-like and growth hormone-like activities in the 
circulation of pregnant goats determined by radioreceptor assays. J. Endocr, 73, 215-226.

Denamur, R., Martinet, J. \& ShORT, R.V. (1973) Pituitary control of the ovine corpus luteum. $J$. Reprod. Fert. 32, 207-220.

DJIANE, J. \& KANN, G. (1975) Prolactin like hormone in ovine placenta: its lactogenic activity. Measurement of its levels during pregnancy. C.r. hebd. Séanc. Acad. Sci., Paris 280, 2785-2788.

FoRSYTH, I.A. (1974) The comparative study of placental lactogenic hormones: a review. In Lactogenic Hormones, Fetal Nutrition and Lactation, pp. 49-67. Eds J. B. Josimovich, M. Reynolds \& E. Cobo. John Wiley \& Sons, New York.

FURR, B.J.A. (1973) Radioimmunoassay of progesterone in peripheral plasma of the domestic fowl in various physiological states and in follicular venous plasma. Acta endocr., Copenh. 72, 89-100.

HeAP, R.B., BedFoRd, C.A. \& LiNzell, J.L. (1975) Metabolic clearance rate, production rate and mammary uptake of progesterone in the goat. J. Endocr. 64, 485-502.
Kaltenbach, C.C., Graber, J.W., Niswender, G.D. \& Nalbandov, A.V. (1968) Effect of hypophysectomy on the formation and maintenance of corpora lutea in the ewe. Endocrinology 82, 753-759.

KanN, G. \& Denamur, R. (1974) Possible rôle of prolactin during the oestrous cycle and gestation in the ewe. J. Reprod. Fert. 39, 473-483.

Kelly, P.A., Robertson, H.A. \& Friesen, H.G. (1974) Temporal pattern of placental lactogen and progesterone secretion in sheep. Nature, Lond. 248, 435-437.

Linzel, J.L. \& HeAP, R.B. (1968) A comparison of progesterone metabolism in the pregnant sheep and goat : sources of production and an estimation of uptake by some target organs. J. Endocr. 41, 433-438.

Nalbandov, A.V. (1973) Control of luteal function in mammals. In Handbook of Physiology, Section 7, volume 2, part 1. pp. 153-167. Eds R. O. Greep \& E. B. Astwood. American Physiological Society, Washington, D.C.

SaIto, T. \& SAXENA, B.B. (1975) Specific receptors for prolactin in the ovary. Acta endocr., Copenh. 80, 126137.

Received 27 July 1977 